\title{
Influence of Vitamin B on Arakawa's Reaction and Lactic Acid Content of Human Milk.
}

I44th Report of the Peroxidase Reaction.

(grst Human Milk Study.)

By

Fumio Ohta.

(太田交雄)

(From the Department of Pediatrics, Faculty of Medicine, Tohoku Imperial University, Sendai.

Director: Prof. A. Sato.)

\section{Introduction.}

In the preceding papers ${ }^{1) 2}$ (140th and 142nd Report of the Peroxidase Reaction), I have made an investigation into the relation between the Arakawa reaction and the lactic acid content of human milk in a fairly large number of milk samples, and found that there was a close relation between them:-A milk sample positive* to Arakaw a's reaction was generally poorer in lactic acid than one negative to it. This is what Yamada) and Sato (Cf. 134th Report of the Peroxidase Reaction) ${ }^{4}$ already stated. I found further that among

1) F. Onta, Further Report of Lactic Acid Content of Human Milk and. Arakawa's Reaction. Part 1. Tohoku J. Exp. Med., 1940, 39, 215.

2) F. Ohta, Further Report of Lactic Acid Content of Human Milk and Arakawa's Reaction. Part 2. Tohoku J. Exp. Med, 1940, 39, 248.

* Arakawarpositive may be used in two different senses. One of these is: Arakawa-positive in a biochemical sense. A sample of human milk is said to have become Arakawa-positive, when it becomes blue on the addition of Arakawa's reagent. There it means that the sample is not negative to Arakawa's reacticn. Arakawa-positive in clinical sense: A sample of human milk is clinically Arakawapositive in clinical sense: A sample of human milk is clinically Arakawa-positive only when it shows such a reaction as $\#$ or $\#$ in one minute of the addition of A $\mathbf{r a -}$ $\mathrm{k} a$ w a's reagent. Another sample of human milk may be Arakawa-positive in the first described sense, bat yet clinically negative.

3) Sh. Yamada, Kioto Furitsu. Ikadaigaku Zassi (Mitt. Med. Akad. Kioto), $1038,22,16$.

4) Sh. Sato, Tohoku J. Exp. Med., 1940, 38, 238. 
mothers with the same intensity of Arakawa's reaction, a milk sample taken from a mother who was taking a vitamin $B^{*}$ preparation was generally poorer in it than that from one who was not. Shoda (Cf. 146th Report of same) ${ }^{5)}$, Y osh in $0^{6)}$, Taka matsu $\mathrm{u}^{7)}$ and Sa to (Cf. 125th Report of same $)^{8}$ of this Laboratory are of opinion that chlorine, inorganic sulphate or methyl glyoxal-like substance, which is generally richer in Arakawa-negative milk than an Arakawa-positive one, will decrease by an administration of vitamin $B$ to an Arakawanegative mother. Takamatsu's) and Orimo (Cf. 106th and 108th Reports of same $)^{10)}$ reported that glyoxalase, which is generally poorer in Arakawa-negative milk than in Arakawa-positive milk, will increase by an administration of vitamin $B$ to an Arakawa-negative mother.

In the present papex, I shall report of the influence of vitamin $B$ on A rakawa's reaction and lactic acid content of human milk.

\section{Method of Experiment.}

1. Materials.

Milk samples were taken from mothers of sick infants who visited our Dispensary, or who were admitted to our Department. To these lactating women $I$ administered a vitamin $B$ preparation subcutaneously or perorally.

For such an experiment, mothers of apparently "healthy" babies would be ideal objects of investigation, because the influence of emotion on Arakawa's reaction (Cf. $72 \mathrm{nd},{ }^{11)} 73 \mathrm{rd}^{12)}$ and $137 \mathrm{th}^{13)}$ Reports of the Peroxidase Reaction and A. Sato' ${ }^{14)}$ treatise) is not negligible. But of course it is very difficult to collect even a few such cases; still more difficult to observe them for a long time.

2. The vitamin B preparation used.

Always "injectio oryzanini" (Sankyo) or powder of oryzanin

* $B$ is meant $B_{I}$ throughout the article.

5) Ky. Shod a, Tohoku J. Exp. Med., 1940.

6) Ky. Yoshino, Tohokn J. Exp. Med., 1988, 33, 576.

7) A. Takamatsu, Tohoku J. Exp. Med., 1934, 23, 46.

8) Sh. Sato, Tohoku J. Exp. Med., 1939, 37, 230.

9) A. Takamatsu, Tohoku J. Exp. Med., 1938, 34, 509.

10) R. Orimo, Tohoku J. Exp. Med., 1939, 35, 48.

11) A. Sato and Y. Moriwaki, Tohoku J. Exp. Med., 1936, 29, 384.

12) J. Asano and M. Hasegawa, Tohokr J. Exp. Med., 1936, 29, 393.

13) H. Umemura, Tohoku J. Exp. Med., 1940.

14) A. Sato, Nisshin Chiryo, 1937, No, 230,69. 
(Sankyo) was used. The amount or unit used in each case is shown in Table 1.

3. Determination of lactic acid in milk.

Tsukazaki's ${ }^{15)}$ micromethod was used. Milk of a given mother was examined before the experiment, or before the first administration of vitamin $\mathrm{B}$, and then repeatedly with about an interval of more than a week during the time of experiment. Milk samples were put to determination as soon as they were obtained, for, according to $\mathrm{Y}$ a m a$\mathrm{d} \mathrm{a}^{3}$, lactic acid content of a milk sample will increase gradually after obtaining.

\section{Result of Experiment.}

The results of my experiment are shown in Table 1.

I shall follow my cases one by one in the following:-

Case 1. By a subcutaneous administration of vitamin B to the mother, her Arakawa's reaction improved slightly on both breasts, and antecedent to it, lactic acid content of her milk became smaller and smaller.

Case 2. By a subcutaneons administration of vitamin B to the mother, her A rakawa's reaction improved remarkably on both breasts, while lactic acid content of milk samples showed only a slight decrease. This woman stopped visiting our Dispensary as soon as her infant had recovered from illness, so I was unable to continue the experiment. But if I had been able to follow her longer, the content of the acid doubtless would have been made much smaller.

Case 3. In this case, the mother had been injected with vitamin $B$ for about 3 weeks, but Arakawa's reaction of her milk improved scarcely* and lactic acid content of milk samples showed only a slight decrease. She was ill of nephritis, and it is difficult to improve the milk in such a case, unless a much longer time is spent on treatment.

Case 4. By a subcutaneous administration of vitamin B to this person, her A rakawa's reaction improved scarcely*, but lactic acid content of milk samples showed a moderate decrease.

Case 5. By a subcutaneous administration of vitamin B on the mother, her A rakawa's reaction improved scarcely*, but lactic acid content of milk samples showed a moderate decrease.

Case 6. A subcutaneous administration of vitamin B to this mother caused her Arakawa's reaction to show a remarkable improvement on both breasts, accompanied by a rather remarkable decrease of lactic acid content.

Case 7. By a subcutaneous and peroral administration of vitamin $\mathbf{B}$ to the mother, her A rakawa's reaction improved remarkably on both breasts,

15) Ry. Tsukazaki, Tohoku J. Exp. Med,, 1925, 5, 429.

* "Improved scarcely" means the reaction up to the 5 th minute of the reaction: (-) $5^{\prime}$ may mean $( \pm) 6^{\prime},(+4) 10^{\prime}$ or even $(-) 15^{\prime}$. 
and antecedent to it, lactic acid content became smaller and smaller.

Case 8. By a subcutaneous administration of vitamin B to this woman, her Arakawa's reaction of the stronger (right) side became weaker, while that of the weaker (left) side became stronger, and in spite of such a change of Arakawa's reaction, lactic acid content showed a remarkable decrease on both breasts.

Case 9. Here a peroral administration of vitamin B caused Arakawa's reaction to show a decided improvement, accompanied by a remarkable decrease of lactic acid content on both breasts.

Case 10. A subcutaneous administration of vitamin B was given to the mother, and her Arakawa's reaction showed a distinct improvement, accompanied by a remarkable decrease of lactic acid content on both breasts.

Case 11. Following a peroral administration of vitamin $B$ to this case, Arakawa's reaction showed only a slight improvement, accompanied by a rather slight decrease of lactic acid content on both breasts. However, the amount of the given vitamin $B$ preparation was smaller than that given to others.

Case 12. By a subcutaneous administration of vitamin B to the mother, her A rakaw a's reaction improved slightly, but lactic acid content decreased moderately on both breasts.

\section{Discussion.}

From the results above described it will be distinctly seen that, by a subcutaneous or peroral administration of vitamin $B$ to mothers with milk negative to Arakaw a's reaction, the lactic acid content of their milks will decrease (Cf. Table 1).

Now; Kitamura's ${ }^{16)}$ experiment is very interesting to me. $\mathrm{He}$ reported that in rabbits, the amount of lactic acid contained in blood was made larger remarkably as they had been put into a B-avitaminotic state, but that the larger content of lactic acid could be reduced to the normal limit by an administration of vitamin $B$. Further, the works of Takamatsu, ${ }^{7) 9}, \mathrm{Sato}^{8)}$ and $\mathrm{Orimo}{ }^{10)}$ of this Laboratory are very interesting too. Takamats $\mathrm{u}^{7)}$ and $\mathrm{Sato}^{8)}$ reported that methyl glyoxal-like substance is generally richer in milk negative to A rakawa's reaction than that positive to it, but that substance in Arakawa-negative milk decreased or disappeared by an administration of vitamin B to an Arakawa-negative mother. And Takamatsu ${ }^{97}$ and $\mathrm{Orim} \mathrm{o}^{10)}$ reported that glyoxalase is generally poorer in Arakawanegative milk than in Arakawa-positive milk, but the enzyme in Arakawa-negative milk increased by an administration of vitamin $B$ to

16) M. Kitamura, Nippon Shokwakibyo Gakkwai Zassi, 1938, 37, 354. 
TABLE 1. Influcnee of vitamin B on Arakawa's reaction

\begin{tabular}{|c|c|c|c|c|c|c|}
\hline \multirow{2}{*}{$\begin{array}{l}\text { No. of } \\
\text { cases }\end{array}$} & \multirow{2}{*}{$\begin{array}{c}\text { Name } \\
\text { and age } \\
\text { of } \\
\text { infants } \\
\text { m= } \\
\text { month }\end{array}$} & \multirow{2}{*}{$\begin{array}{c}\text { Name } \\
\text { and Age } \\
\text { of } \\
\text { mothers } \\
y=\text { years }\end{array}$} & \multirow{2}{*}{$\begin{array}{c}\text { Diagnosis } \\
\text { of infant }\end{array}$} & \multirow{2}{*}{$\begin{array}{l}\text { Date of } \\
\text { experi- } \\
\text { ment }\end{array}$} & \multicolumn{2}{|c|}{ Arakawa's reaction } \\
\hline & & & & & \begin{tabular}{lllll}
\multicolumn{6}{c}{$\begin{array}{c}\text { Right } \\
0^{\prime}\end{array} 1^{\prime}$} & $2^{\prime}$ & $3^{\prime}$ & $4^{\prime}$ & $5^{\prime}$ \\
\end{tabular} & \begin{tabular}{lllll}
\multicolumn{6}{c}{ Left } \\
$\begin{array}{llllll} & & & \\
0^{\prime} & 1^{\prime} & 2^{\prime} & 3^{\prime} & 4^{\prime} & 5^{\prime} \\
\end{array}$
\end{tabular} \\
\hline 1 & $\begin{array}{l}\text { N.E. } \\
3 \mathrm{~m}\end{array}$ & $\begin{array}{l}\text { C.E. } \\
33 \text { y }\end{array}$ & $\begin{array}{c}\text { Infantile } \\
\text { pre- } \\
\text { beriberi }\end{array}$ & $\begin{array}{l}\text { 20. XI } \\
\text { 29. " } \\
\text { 5. XII } \\
\text { 12. " } \\
91 . "\end{array}$ & $\begin{array}{l}------ \\
------ \\
--- \pm \\
- \pm \pm \pm+ \pm \\
- \pm \pm \pm+\end{array}$ & $\begin{array}{l}---- \pm- \\
- \pm- \pm \pm \\
- \pm \pm+ \pm \\
- \pm-- \pm \pm\end{array}$ \\
\hline 2 & $\begin{array}{l}\text { T.S. } \\
3 \mathrm{~m}\end{array}$ & $\begin{array}{l}\text { T.S. } \\
28 \mathrm{y}\end{array}$ & $\begin{array}{c}\text { Broncho- } \\
\text { pneumonia }\end{array}$ & $\begin{array}{l}\text { 20. XII } \\
27 . \pi\end{array}$ & $\begin{array}{l}--\overline{-} \pm \pm \\
- \pm++ \pm\end{array}$ & $-\bar{t}+ \pm \pm \frac{ \pm}{H}$ \\
\hline 3 & $\begin{array}{l}\text { S.T. } \\
2 \mathrm{~m}\end{array}$ & $\begin{array}{l}\text { T.T. } \\
23 \mathrm{y}\end{array}$ & $\begin{array}{l}\text { B-avita- } \\
\text { minotic } \\
\text { dyspepsia }\end{array}$ & $\begin{array}{l}\text { 3. XII } \\
10 . " \\
17 . " \\
24 . "\end{array}$ & $\begin{array}{l}------ \\
--- \pm \pm \\
---- \pm- \pm\end{array}$ & $\begin{array}{l}------ \\
----- \\
-----\end{array}$ \\
\hline 4 & $\begin{array}{l}\text { Y.K. } \\
10 \mathrm{~m}\end{array}$ & $\begin{array}{l}\text { R.K. } \\
22 \mathrm{y}\end{array}$ & $\begin{array}{c}\text { Brone- } \\
\text { pneumonia }\end{array}$ & $\begin{array}{l}29 . \mathrm{XII} \\
9 . \mathrm{I} \\
22 .\end{array}$ & $\begin{array}{l}----- \\
------ \\
------\end{array}$ & $\begin{array}{l}------ \\
-----1 \\
----1\end{array}$ \\
\hline 5 & $\begin{array}{l}\text { H.T. } \\
16 \mathrm{~m}\end{array}$ & $\begin{array}{l}\text { M.T. } \\
22 \mathrm{y}\end{array}$ & $\begin{array}{c}\text { Broncho- } \\
\text { pneumonia }\end{array}$ & $\begin{array}{l}\text { 7. I } \\
15 . " \\
25 . "\end{array}$ & $\begin{array}{l}------ \\
------ \\
------\end{array}$ & $\begin{array}{l}------ \\
---- \pm \\
--- \pm \pm\end{array}$ \\
\hline 6 & $\begin{array}{l}\text { M.K. } \\
4 \mathrm{~m}\end{array}$ & $\begin{array}{l}\text { H.K. } \\
32 \text { y }\end{array}$ & $\begin{array}{l}\text { Infantile } \\
\text { diarrhoea }\end{array}$ & $\begin{array}{l}\text { 11. I } \\
16 . " \\
26 . " 7 \\
2 . \text { II }\end{array}$ & $\begin{array}{l}--- \pm-- \\
-- \pm \pm \pm+ \\
-- \pm \pm+t \\
\pm+H+m+m\end{array}$ & $\begin{array}{l}------ \\
--- \pm \pm+ \\
-\bar{t}+ \pm+ \\
\pm H+H \mathrm{H} H\end{array}$ \\
\hline 7 & $\begin{array}{l}\text { T.N. } \\
1 \mathrm{~m}\end{array}$ & $\begin{array}{l}\text { R.N. } \\
22 \mathrm{y}\end{array}$ & Atrophy & $\begin{array}{l}\text { 24. I } \\
\text { 1. II } \\
9 . " \\
17 . "\end{array}$ & $\begin{array}{l}------ \\
- \pm- \pm \pm \\
- \pm+ \pm+4\end{array}$ & $\begin{array}{l}------ \\
---- \pm \\
\pm- \pm \pm+ \pm \\
\pm+ \pm+1+\end{array}$ \\
\hline 8 & $\begin{array}{l}\text { C.O. } \\
7 \mathrm{~m}\end{array}$ & $\begin{array}{l}\mathrm{K.O} \\
33 \mathrm{y}\end{array}$ & $\begin{array}{c}\text { Infantile } \\
\text { pre- } \\
\text { beriberi }\end{array}$ & $\begin{array}{l}20 . \text { II } \\
28 . \text { " } \\
7 . \text { III }\end{array}$ & $\begin{array}{l} \pm+H+H H \\
=+H+H \\
-+++H+H\end{array}$ & $\begin{array}{l}-- \pm--- \pm \\
- \pm \pm+ \pm+\end{array}$ \\
\hline 9 & $\begin{array}{l}\text { S.H. } \\
5 \mathrm{~m}\end{array}$ & $\begin{array}{l}\text { F.H. } \\
29 \mathrm{y}\end{array}$ & $\begin{array}{c}\text { Bronchitis } \\
\text { acuta }\end{array}$ & $\begin{array}{l}\text { 6. III } \\
\text { 17. } \\
29 .\end{array}$ & $\begin{array}{l}- \pm+++H \\
-+H+H+H \\
\pm+H H H\end{array}$ & $\begin{array}{l}- \pm++ \pm+H \\
\pm+H+H+H \\
\pm H+H H+H\end{array}$ \\
\hline 10 & $\begin{array}{l}\text { E.O. } \\
4 \mathrm{~mm}\end{array}$ & $\begin{array}{l}\mathrm{T} .0 \\
25 \mathrm{y}\end{array}$ & $\begin{array}{l}\text { Hypotro- } \\
\text { phy }\end{array}$ & $\begin{array}{l}\text { 16. III } \\
23 .{ }^{n} \\
30 .{ }^{n}\end{array}$ & $\begin{array}{l}--\overline{-}- \pm \\
- \pm+++4 \\
\pm+H+H\end{array}$ & $\begin{array}{l}----\overline{-} \\
\pm \pm+H+H \\
\pm \pm+H+H\end{array}$ \\
\hline 11 & K.o. & S. 0 . & $\begin{array}{c}\text { Infantile } \\
\text { pre- } \\
\text { beriberi }\end{array}$ & $\begin{array}{l}\text { 3. V } \\
13 . \\
20 .\end{array}$ & $\begin{array}{l}-- \pm \pm+ \\
-- \pm \pm++ \\
- \pm \pm+++\end{array}$ & $\begin{array}{l}- \pm+++ \\
- \pm \pm+t+ \\
- \pm++t\end{array}$ \\
\hline 12 & $\begin{array}{l}\mathrm{T} \cdot \mathrm{K} . \\
\mathrm{2} \mathrm{m}\end{array}$ & $\begin{array}{l}\text { C.K. } \\
38 \mathrm{y}\end{array}$ & Dyspepsia & $\begin{array}{l}\text { 15. VI } \\
24 . n \\
30 . n\end{array}$ & $\begin{array}{l}----- \\
----- \pm \\
---- \pm\end{array}$ & $\begin{array}{l}-- \pm-\overline{-} \\
-- \pm++4 \\
- \pm \pm++\end{array}$ \\
\hline
\end{tabular}

* "Oryzanin" fortified 10 times is a preparation of vitamin $B_{1}$ for injection, containing 0.5 mgrms. of vitamin $B_{1}$ crystal, 333 international units, in 1 c.c.

8 "Oryzanin" fortified 20 times is a preparation of vitamin $B_{1}$, for injection 
and lactic acid content of human milk.

\begin{tabular}{|c|c|c|}
\hline \multicolumn{2}{|c|}{$\begin{array}{l}\text { Lactic acid content } \\
\quad(\text { mgrms. \%) }\end{array}$} & \multirow{2}{*}{ Remarks } \\
\hline Right & Left & \\
\hline $\begin{array}{r}19.5 \\
16.2 \\
11.9 \\
9.0 \\
7.9\end{array}$ & $\begin{array}{r}12.0 \\
9.0 \\
9.6 \\
6.2 \\
6.0\end{array}$ & $\begin{array}{l}\text { Has been injected with "oryzanin" fortified } 10 \text { times* } \\
1 \text { c.c. once a day since } 21 \text {. XI. } \\
\text { Decrease of lactic acid remarkable. }\end{array}$ \\
\hline $\begin{array}{l}18.5 \\
15.6\end{array}$ & $\begin{array}{r}10.1 \\
9.6\end{array}$ & $\begin{array}{l}\text { Has been injected with "oryzanin" fortified } 10 \text { times } \\
\text { l c.c. once a day since } 21 \text {. XII and inclination of decrease } \\
\text { of lactic acid. }\end{array}$ \\
\hline $\begin{array}{l}13.5 \\
12.0 \\
12.9 \\
13.2\end{array}$ & $\begin{array}{l}18.0 \\
16.5 \\
16.2 \\
15.8\end{array}$ & $\begin{array}{l}\text { Mother was ill of acuta nephritis and has been injected } \\
\text { with "oryzanin" fortified } 20 \text { times§ } 1 \text { c.c. once every } \\
\text { other day since } 5 \text {. XII. } \\
\text { Inclination of decrease of laetic acid. }\end{array}$ \\
\hline $\begin{array}{l}16.8 \\
13.5 \\
10.1\end{array}$ & $\begin{array}{r}12.0 \\
10.9 \\
9.6\end{array}$ & $\begin{array}{l}\text { Has been injected with "oryzanin" fortified } 10 \text { times } \\
\text { once a day since } 30 \text {, XII. } \\
\text { Inclination of decrease of lactic acid. }\end{array}$ \\
\hline $\begin{array}{r}14.2 \\
11.3 \\
9.7\end{array}$ & $\begin{array}{r}10.1 \\
6.3 \\
8.4\end{array}$ & $\begin{array}{l}\text { Has been injected with "oryzanin" fortified } 10 \text { times } \\
1 \text { c.c. once a day since } 8.1 \text {. } \\
\text { Decrease of lactic acid remarkable. }\end{array}$ \\
\hline $\begin{array}{l}9.8 \\
9.0 \\
5.6 \\
5.3\end{array}$ & $\begin{array}{l}8.4 \\
9.0 \\
5.2 \\
5.6\end{array}$ & $\begin{array}{l}\text { Has been injected with "oryzanin" fortified } 10 \text { times } \\
1 \text { c.c. once a day since } 12 . \mathrm{I} \text {. } \\
\text { Decrease of lactic acid remarkable. }\end{array}$ \\
\hline $\begin{array}{r}16.8 \\
14.7 \\
10.2 \\
6.8\end{array}$ & $\begin{array}{r}13.5 \\
9.2 \\
4.8 \\
5.4\end{array}$ & $\begin{array}{l}\text { Has been injected with } 10 \text { times fortified oryzanin } 1 \text { c.c. } \\
\text { once a day since } 25.1 \text { to } 12 . \text { II and given perorally } \\
\text { "oryzanin" powdert } 6 \text { grm. daily since } 26 . I \text {. } \\
\text { Decrease of lactic acid remarkable. }\end{array}$ \\
\hline $\begin{array}{r}12.3 \\
7.2 \\
6.3\end{array}$ & $\begin{array}{r}18.0 \\
13.5 \\
8.4\end{array}$ & $\begin{array}{l}\text { Has been injected with "oryzanin" fortified } 10 \text { times } \\
1 \text { c.c. once a day since } 21 \text {. II. } \\
\text { Decrease of lactic acid remarkable. }\end{array}$ \\
\hline $\begin{array}{r}14.1 \\
12.3 \\
7.2\end{array}$ & $\begin{array}{l}19.2 \\
14.6 \\
10.2\end{array}$ & $\begin{array}{l}\text { Has been taking "oryzanin" powder } 10 \text { grm. daily } \\
\text { perorally since 7. III. } \\
\text { Decrease of lactic acid remarkable. }\end{array}$ \\
\hline $\begin{array}{r}16.5 \\
12.9 \\
9.6\end{array}$ & $\begin{array}{l}20.4 \\
17.4 \\
13.5\end{array}$ & $\begin{array}{l}\text { Has been injected with "oryzanin fortified } 20 \text { times } \\
\text { I c.c. once every other day since } 18 . \text { III. } \\
\text { Decrease of lactie acid remarkable. }\end{array}$ \\
\hline $\begin{array}{l}13.6 \\
12.5 \\
12.0\end{array}$ & $\begin{array}{r}12.8 \\
10.2 \\
9.6\end{array}$ & $\begin{array}{l}\text { Has been taking "oryzanin" powder } 3 \text { grm. daily pe- } \\
\text { rorally since } 4 \text {. V. } \\
\text { Inclination of decrease of lactic acid. }\end{array}$ \\
\hline $\begin{array}{l}18.3 \\
15.9 \\
14.3\end{array}$ & $\begin{array}{l}16.2 \\
10.2 \\
12.3\end{array}$ & $\begin{array}{l}\text { Has been injected with "oryzanin" fortified } 20 \text { times } \\
1 \text { c.c. once every other day since } 17 . V I \text {. } \\
\text { Inclination of deerease of lactic acid. }\end{array}$ \\
\hline
\end{tabular}

containing $1.0 \mathrm{mgrm}$. of vitamin $B_{1}$ crystal, 666 I.N.U., in 1 c.c.

$\dagger$ "Oryzanin" powder is a preparation of vitamin $B_{1}$ for peroral use, containing 40 I.N.U. in $1 \mathrm{grm}$. 
the mother. And the relation in the carbohydrate metabolism between methyl glyoxal, glyoxalase, and lactic acid is known as follows:-

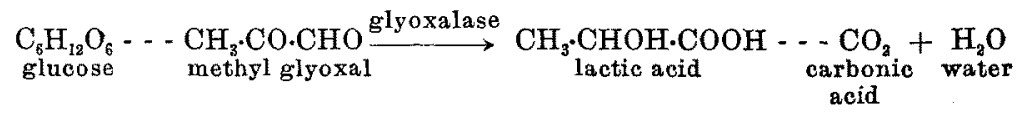

Comparing this relation with Kitamura's ${ }^{16)}$, Takamatsu's' ${ }^{7)}$, Sato's ${ }^{8)}$ and Orimo's ${ }^{10)}$ results, one can presume easily that the lactic acid content of Arakawa-negative milk will be made smaller by an administration of vitamin $B$ to the Arakawa-negative mother.

On the other hand, it must be remarked that in the cases: Nos. $1,4,5$ and 7 , lactic acid content of milk became smaller, antecedent to the improvement of Arakaw a's reaction (Cf. Table 1). Takamats $u^{\prime} s^{7)}$ pointed out that, when vitamin $B$ was administered to mothers with Arakawa-negative milk, the reaction remained sometimes still Arakawa-negative, in spite of losing in the toxicity of the milk, or of a decrease of methyl glyoxal-like substance. From this paper, it is natural that lactic acid content of Arakawa-negative milk will decrease, antecedent to an improvement of A rak a wa's reaction.

In the preceding papers ${ }^{12)}$, I reported that, among mothers with milk of the same intensity of Arakawa's reaction, a mother with vitamin B intake is generally poorer in lactic acid than that of one without it. This result coincides with the result reported in the present paper, because, following not only a subcutaneous injection, but also a peroral administration of vitamin $B$ preparation the lactic acid content of milk will decrease. Besides, the result that an improvement of Arakawa's reaction often lags behind the decrease of the acid is further coincident with the result above mentioned.

Remarks.

As has been related above, the present investigation was a clinical experiment, and at the same time a therapeutically important procedure. The result would have been more interesting if each case had been observed for a much longer time. In the cases: Nos. 1,6 and 7 (Cf. Table 1), in which the experiment was performed for a relatively longer time, the decrease of the amount of lactic acid contained in the milk was very remarkable. On the contrary, in the other cases (except for No. 3) with only a short time of experiment, the reduction of lactic acid content was not so much. It will thus be seen that for the purpose of decreasing lactic acid content of Arakawa-negative milk, a large 
amount of vitamin $\mathrm{B}$ ought to be given for as long a time as possible. As to the way of administration, a subcutaneous administration will generally be better, if especially the possibility of an "enteral" avitaminosis $\mathrm{B}$ is taken into consideration. A $\mathrm{mmon}{ }^{17}$ ) is of opinion that the vitamins can not be easily absorbed through the atrophic mucous membrane of the gastro-intestinal canal of an avitaminotic body.

\section{Summary.}

In the preceding papers ${ }^{1 / 2)}$, I ascertained that Arakawa-negative milk contains generally a larger amount of lactic acid than Arakawapositive milk, as $\mathrm{Yamad} \mathrm{a}{ }^{3)}$ and $\mathrm{Sato}^{4)}$ already stated. In the present paper, I was able to reduce the amount of lactic acid in Arakawanegative milk by a subcutaneous or peroral administration of vitamin $B$ to 12 lactating mothers with Arakawa-negative milk. From this outcome of my own experiment and Kitamura's ${ }^{16)}$ result, we may conclude that Arakawa-negative milk is a milk from a $\mathrm{B}$-avitaminotic body from the view point of lactic acid, and it is then quite natural that such a milk can be made poorer in the lactic acid content by an administration of vitamin $B$.

\section{Conclusion.}

As already reported, human milk negative to Arakawa's reaction contains a large amount of lactic acid, while Arakawa-positive milk contains a small amount of it, and Arakawa-negative milk is milk from a $B$-avitaminotic mother. If vitamin $B$ is administered to a mother with milk negative to Arakawa's reaction (that is, with milk of a large amount of lactic acid), then the lactic acid content will be reduced.

The following table shows the amount of lactic acid in strongly Arakawa-negative milk. It ought to have been printed on P. 220 of the 140th Report of the Peroxidase Reaction, Further Report of Lactic Acid Content of Human Milk and A rakaw a's Reaction (Part 1).* In this Report Table 4 was missing between Table 3 (p. 219) and Table 5 (s. 220).

17) R. A mmon, Klin, Wschr., 1938, 17, 1825.

* E. O hta, Tohoku J. Exp. Med., 1940, 39, 215. 


\section{TABLE 4.}

The amount of lactic acid contained in completely or almost Arakawanegative milk with $(-) 1^{\prime}$ or $(-) 5^{\prime}$ reaction.

\begin{tabular}{|c|c|c|c|c|c|c|c|}
\hline $\begin{array}{l}\text { No. } \\
\text { of } \\
\text { case }\end{array}$ & $\begin{array}{l}\text { Month of } \\
\text { ex- } \\
\text { periment }\end{array}$ & $\begin{array}{c}\text { Age of } \\
\text { mother or } \\
\text { infant } \\
\begin{array}{c}y=\text { year } \\
m=\text { month } \\
d=\text { day }\end{array}\end{array}$ & $\begin{array}{c}\text { Has mother } \\
\text { been taking } \\
\text { vitamin B } \\
\text { preparation? }\end{array}$ & $\begin{array}{l}\text { Was infant } \\
\text { exclusively } \\
\text { breast-fed? }\end{array}$ & $\mid \begin{array}{l}\text { Side of } \\
\text { breast } \\
\mathrm{R}=\text { right } \\
\mathrm{L}=\text { left }\end{array}$ & $\begin{array}{l}\text { Ara- } \\
\text { kawa'st } \\
\text { reaction }\end{array}$ & $\begin{array}{c}\text { Lactic acid } \\
\text { content } \\
\text { (mgrms. } \\
\% \text { ) }\end{array}$ \\
\hline $2 *$ & $\mathrm{X}$ & $\begin{array}{l}21 \mathrm{y} \\
13 \mathrm{~m}\end{array}$ & Yes\$ & No & L & $4(-)$ & 12.9 \\
\hline 3 & $\Rightarrow$ & $\begin{array}{l}40 \mathrm{y} \\
5 \mathrm{~m}\end{array}$ & Yes & $\dot{f}$ & $\begin{array}{l}\mathrm{R} \\
\mathrm{L}\end{array}$ & $\begin{array}{l}16(-) \\
15(-)\end{array}$ & $\begin{array}{l}15.5 \\
14.6\end{array}$ \\
\hline 4 & $n$ & $\begin{array}{c}32 y \\
9 \mathrm{~m}\end{array}$ & Yes & & $\begin{array}{l}\mathbf{R} \\
\mathrm{L}\end{array}$ & $\begin{array}{l}13(-) \\
11(-)\end{array}$ & $\begin{array}{l}9.5 \\
9.0\end{array}$ \\
\hline $9^{* 4}$ & XI & $\begin{array}{l}29 \mathrm{~g} \\
9 \mathrm{~m}\end{array}$ & - $\quad * * *$ & & $\mathrm{R}$ & $10(-)$ & 9.8 \\
\hline 10 & $n$ & $\begin{array}{l}21 \mathrm{y} \\
32 \mathrm{~d}\end{array}$ & Yes & & $\begin{array}{l}\mathrm{R} \\
\mathrm{L}\end{array}$ & $\begin{array}{l}16(-) \\
16(-)\end{array}$ & $\begin{array}{r}11.5 \\
9.0\end{array}$ \\
\hline 11 & $"$ & $\begin{array}{l}29 \mathrm{~g} \\
2 \mathrm{~m}\end{array}$ & & & $\begin{array}{l}\mathbf{R} \\
\mathrm{L}\end{array}$ & $\begin{array}{l}16(-) \\
16(-)\end{array}$ & $\begin{array}{l}18.0 \\
16.5\end{array}$ \\
\hline 12 & $\pi$ & $\begin{array}{l}36 \mathrm{y} \\
3 \mathrm{~m}\end{array}$ & & $\therefore$ & $\begin{array}{l}\mathbf{R} \\
\mathrm{L}\end{array}$ & $\begin{array}{l}16(-) \\
16(-)\end{array}$ & $\begin{array}{l}19.5 \\
12.0\end{array}$ \\
\hline $13^{*}$ & $n$ & $\begin{array}{l}28 \mathrm{y} \\
12 \mathrm{~m}\end{array}$ & & No & $\mathrm{L}$ & $10(-)$ & 9.5 \\
\hline 16 & $n$ & $\begin{array}{l}29 \mathrm{y} \\
11 \mathrm{~m}\end{array}$ & & & $\begin{array}{l}\mathrm{R} \\
\mathrm{L}\end{array}$ & $\begin{array}{l}16(-) \\
16(-)\end{array}$ & $\begin{array}{l}22.5 \\
12.6\end{array}$ \\
\hline $18 *$ & " & $\begin{array}{l}27 \mathrm{y} \\
8 \mathrm{~m}\end{array}$ & Yes & & $\mathrm{R}$ & $14(-)$ & 15.7 \\
\hline 19 & $"$ & $\begin{array}{l}23 \mathrm{y} \\
43 \mathrm{~d}\end{array}$ & Yes & & $\begin{array}{l}\mathrm{R} \\
\mathrm{L}\end{array}$ & $\begin{array}{l}16(-) \\
16(-)\end{array}$ & $\begin{array}{l}18.0 \\
16.5\end{array}$ \\
\hline 20 & $n$ & $\begin{array}{l}41 \mathrm{y} \\
44 \mathrm{~d}\end{array}$ & & No & $\begin{array}{l}\mathrm{R} \\
\mathrm{L}\end{array}$ & $\begin{array}{l}16(-) \\
16(-)\end{array}$ & $\begin{array}{l}13.2 \\
10.8\end{array}$ \\
\hline 21 & XII & $\begin{array}{r}24 \mathrm{y} \\
3 \mathrm{~m}\end{array}$ & & & $\begin{array}{l}\mathrm{R} \\
\mathrm{L}\end{array}$ & $\begin{array}{l}16(-) \\
16(-)\end{array}$ & $\begin{array}{l}18.5 \\
10.2\end{array}$ \\
\hline 23 & $n$ & $\begin{array}{l}21 \mathrm{y} \\
11 \mathrm{~m}\end{array}$ & & No & $\begin{array}{l}\mathrm{R} \\
\mathrm{L}\end{array}$ & $\begin{array}{l}16(-) \\
16(-)\end{array}$ & $\begin{array}{r}10.5 \\
9.6\end{array}$ \\
\hline 24 & $n$ & $\begin{array}{r}41 \mathrm{y} \\
7 \mathrm{~m}\end{array}$ & & & $\begin{array}{l}\mathrm{R} \\
\mathrm{L}\end{array}$ & $\begin{array}{l}16(-) \\
16(-)\end{array}$ & $\begin{array}{l}16.2 \\
15.3\end{array}$ \\
\hline $28 *$ & $n$ & $\begin{array}{r}25 \mathrm{y} \\
5 \mathrm{~m}\end{array}$ & Yes & & $\mathrm{R}$ & $\S$ & 15.0 \\
\hline
\end{tabular}


TABle 4. Continued.

\begin{tabular}{|c|c|c|c|c|c|c|c|}
\hline $\begin{array}{l}\text { No. } \\
\text { of } \\
\text { case }\end{array}$ & $\begin{array}{l}\text { Month of } \\
\text { ex- } \\
\text { periment }\end{array}$ & \begin{tabular}{|c|} 
Age of \\
mother or \\
infant \\
$y=$ years \\
$m=$ months \\
$d=$ days
\end{tabular} & \begin{tabular}{|c|} 
Has mother \\
been taking \\
vitamin $B$ \\
preparation?
\end{tabular} & $\begin{array}{l}\text { Was infant } \\
\text { exclusively } \\
\text { breast-fed? }\end{array}$ & $\begin{array}{c}\text { Side of } \\
\text { breast } \\
\mathrm{R}=\text { right } \\
\mathrm{L}=\text { left }\end{array}$ & $\begin{array}{l}\text { Ara- } \\
\text { kawa's } \\
\text { reaction }\end{array}$ & $\begin{array}{c}\text { Lactic acid } \\
\text { content } \\
\text { (mgrms. } \\
\% \text { ) }\end{array}$ \\
\hline $31^{*}$ & XII & $\begin{array}{l}22 \mathrm{~g} \\
11 \mathrm{~m}\end{array}$ & Yes & No & $\mathbf{R}$ & $14(-)$ & 9.6 \\
\hline 32 & $"$ & $\begin{array}{l}27 \mathrm{~g} \\
10 \mathrm{~m}\end{array}$ & & & $\begin{array}{l}\mathbf{R} \\
\mathbf{L}\end{array}$ & $\begin{array}{r}16(-) \\
3(-)\end{array}$ & $\begin{array}{l}15.0 \\
10.5\end{array}$ \\
\hline $33 *$ & $n$ & $\begin{array}{l}25 \mathrm{y} \\
12 \mathrm{~m}\end{array}$ & Yes & & L & $11(-)$ & 10.8 \\
\hline 34 & $\pi$ & $\begin{array}{r}27 \mathrm{y} \\
3 \mathrm{~m}\end{array}$ & Yes & & $\begin{array}{l}\mathrm{R} \\
\mathrm{L}\end{array}$ & $\begin{array}{r}11(-) \\
2(-)\end{array}$ & $\begin{array}{l}8.1 \\
7.2\end{array}$ \\
\hline 35 & " & $\begin{array}{l}31 \mathrm{y} \\
10 \mathrm{ma}\end{array}$ & & & $\begin{array}{l}\mathrm{R} \\
\mathrm{L}\end{array}$ & $\begin{array}{l}16(-) \\
16(-)\end{array}$ & $\begin{array}{l}16.5 \\
12.0\end{array}$ \\
\hline $36^{*}$ & I & $\begin{array}{l}38 \mathrm{y} \\
33 \mathrm{~d}\end{array}$ & Yes & & $\mathrm{R}$ & $12(-)$ & 10.8 \\
\hline 37 & $\pi$ & $\begin{array}{l}37 \mathrm{~g} \\
19 \mathrm{~m}\end{array}$ & & No & $\begin{array}{l}\mathrm{R} \\
\mathrm{L}\end{array}$ & $\begin{array}{l}16(-) \\
14(-)\end{array}$ & $\begin{array}{l}18.0 \\
15.0\end{array}$ \\
\hline 38 & 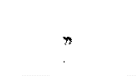 & $\begin{array}{l}22 \mathrm{~g} \\
16 \mathrm{~m}\end{array}$ & Yes & No & $\begin{array}{l}\mathbf{R} \\
\mathbf{L}\end{array}$ & $\begin{array}{l}16(-) \\
16(-)\end{array}$ & $\begin{array}{l}14.2 \\
10.8\end{array}$ \\
\hline 40 & $n$ & $\begin{array}{r}32 \mathrm{y} \\
4 \mathrm{~m}\end{array}$ & Yes & & $\begin{array}{l}\mathrm{R} \\
\mathrm{L}\end{array}$ & $\begin{array}{l}16(-) \\
16(-)\end{array}$ & $\begin{array}{l}9.9 \\
8.4\end{array}$ \\
\hline $4 \dot{1}$ & $n$ & $\begin{array}{r}27 \mathrm{~g} \\
3 \mathrm{~m}\end{array}$ & Yes & No & $\begin{array}{l}\mathrm{R} \\
\mathrm{L}\end{array}$ & $\begin{array}{r}12(-) \\
4(-)\end{array}$ & $\begin{array}{r}12.0 \\
9.6\end{array}$ \\
\hline $42 *$ & $n$ & $\begin{array}{r}35 \mathrm{y} \\
6 \mathrm{~m}\end{array}$ & Yes & No & $\mathrm{R}$ & $8(-)$ & 10.1 \\
\hline 43 & $n$ & $\begin{array}{r}24 \mathrm{y} \\
2 \mathrm{~m}\end{array}$ & & & $\begin{array}{l}\mathrm{R} \\
\mathrm{L}\end{array}$ & $\begin{array}{l}6(-) \\
8(-)\end{array}$ & $\begin{array}{l}16.5 \\
10.5\end{array}$ \\
\hline 44 & $\gg$ & $\begin{array}{l}25 \mathrm{y} \\
11 \mathrm{~m}\end{array}$ & Yes & No & $\begin{array}{l}\mathrm{R} \\
\mathrm{L}\end{array}$ & $\begin{array}{l}6(-) \\
7(-)\end{array}$ & $\begin{array}{l}7.2 \\
7.5\end{array}$ \\
\hline 45 & r & $\begin{array}{c}35 \mathrm{y} \\
8 \mathrm{~m}\end{array}$ & & & $\begin{array}{l}\mathrm{R} \\
\mathrm{L}\end{array}$ & $\begin{array}{l}16(-) \\
16(-)\end{array}$ & $\begin{array}{l}13.5 \\
15.9\end{array}$ \\
\hline $46^{\circ}$ & $n$ & $\begin{array}{l}23 \mathrm{y} \\
14 \mathrm{~m}\end{array}$ & & No & $\mathrm{R}$ & $4(-)$ & 12.6 \\
\hline $48 *$ & " & $\begin{array}{l}28 \mathrm{~g} \\
7 \mathrm{~m}\end{array}$ & & & $\mathrm{~L}$ & $16(-)$ & 16.5 \\
\hline 50 & " & $\begin{array}{l}22 \mathrm{y} " \\
20 \mathrm{~d}\end{array}$ & Yes & & $\begin{array}{l}\mathbf{R} \\
\mathbf{L}\end{array}$ & $\begin{array}{l}16(-) \\
16(-)\end{array}$ & $\begin{array}{r}11.7 \\
9.2\end{array}$ \\
\hline
\end{tabular}


Table 4. Continued.

\begin{tabular}{|c|c|c|c|c|c|c|c|}
\hline $\begin{array}{l}\text { No. } \\
\text { of } \\
\text { case }\end{array}$ & $\begin{array}{l}\text { Month of } \\
\text { ex- } \\
\text { periment }\end{array}$ & \begin{tabular}{|c|} 
Age of \\
mother or \\
infant \\
$y=$ years \\
m=months \\
$d=$ days \\
\end{tabular} & $\begin{array}{c}\text { Has mother } \\
\text { been taking } \\
\text { vitamin } B \\
\text { preparation? }\end{array}$ & $\begin{array}{l}\text { Was infant } \\
\text { exclusively } \\
\text { breast-fed? }\end{array}$ & $\begin{array}{l}\text { Side of } \\
\text { breast } \\
R=\text { right } \\
L=\text { left }\end{array}$ & $\begin{array}{l}\text { Ara- } \\
\text { kawa's } \\
\text { reaction }\end{array}$ & $\begin{array}{c}\text { Laetic acid } \\
\text { content } \\
\text { (mgrms. } \\
\% \text { ) }\end{array}$ \\
\hline 54 & I & $\begin{array}{c}25 \mathrm{y} \\
3 \mathrm{~m}\end{array}$ & & & $\begin{array}{l}\mathrm{R} \\
\mathrm{L}\end{array}$ & $\begin{array}{l}16(-) \\
16(-)\end{array}$ & $\begin{array}{l}9.9 \\
7.5\end{array}$ \\
\hline $55^{*}$ & $\Rightarrow$ & $\begin{array}{r}21 \mathrm{~g} \\
4 \mathrm{~m}\end{array}$ & Yes & & $\mathbf{R}$ & $15(-)$ & 8.2 \\
\hline $57 *$ & II & $\begin{array}{l}29 \mathrm{~g} \\
12 \mathrm{~m}\end{array}$ & & No & $\mathbf{R}$ & $8(-)$ & 9.9 \\
\hline 58 & $n$ & $\begin{array}{l}23 \mathrm{y} \\
12 \mathrm{~m}\end{array}$ & & No & $\begin{array}{l}\mathrm{R} \\
\mathbf{L}\end{array}$ & $\begin{array}{l}16(-) \\
16(-)\end{array}$ & $\begin{array}{l}18.3 \\
16.5\end{array}$ \\
\hline 63 & $n$ & $\begin{array}{l}24 \mathrm{y} \\
24 \mathrm{~m}\end{array}$ & & No & $\frac{\mathbf{R}}{\mathrm{L}}$ & $\begin{array}{l}16(-) \\
11(-)\end{array}$ & $\begin{array}{r}10.2 \\
6.6\end{array}$ \\
\hline & & & & & & $\begin{array}{l}\text { Average } \\
\text { Maximum } \\
\text { Minimam }\end{array}$ & $\begin{array}{r}12.3 \\
22.5 \\
6.6\end{array}$ \\
\hline
\end{tabular}

$*, \dagger, \S, \ddagger$ Cf. Foot note to Table 1. (in the 140th Report ${ }^{1}$ ) of the Peroxidase Reaction.)

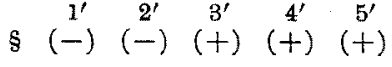

Conclusion.

The Conclusion of the present paper will be found on page 35 . 